As only two or three days remained, the Society immediately began a campaign by telephone and telegraph, communicating with the Department of Commerce, Congressmen and friends, and particularly with the Library of Congress and the Chairman of the Congressional Committee on the Disposal of Waste Paper. The Society took the position that such a sale was illegal under an executive order issued by President Taft, but that if it could not be prevented, the Society desired to enter its bid and provide for the preservation of the material. Exactly what could be done with some forty tons of old papers remained somewhat problematical. Fortunately, however, a telegram was received the day before the sale of the papers that the Library of Congress and the Customs Division, with the assistance of other government departments, had stopped the proceedings and were actively considering the best method for their preservation. An extract from a letter received from the Chief of the Manuscript Department of the Library of Congress will perhaps tell its own story and indicate that this action on the part of the Society may have accomplished more than the saving of this particular lot of documents.

"I believe that the representations on behalf of the Library to the Commissioner of Customs here," he writes, "have checked any similar movements toward destruction in other parts. It appears that the collector at Philadelphia, and I presume that the same is true of other collectors, was not aware of the executive order. . .

We are all greatly obliged to the officers of The Business Historical Society for calling our attention to the proposed sale and probable destruction of papers."

\title{
The Oldest Joint-Stock Company
}

WE ARE indebted to Mr. E. A. S. Clarke, Secretary of the American Iron and Steel Institute, for calling our attention to an article in the IgOI Transactions of the British Institute which places the oldest joint-stock enterprise in the world at Domnarfvet, Sweden. It is the Stora Kopparbergs (Great Copper Mountain) Mining Company, deriving its name from the celebrated copper mine at Falun, where one of its plants is located.

In I896, the Company celebrated its 550 th anniversary, dating from its oldest charter; and a deed for the transfer of shares in the Company dated 1288 is still in existence in the State archives. Its 
real estate comprises vast forest lands, copper and iron mines, and waterfalls representing 100,000 horsepower. Its ironworks at Domnarfvet are the largest in Scandinavia, and the largest using charcoal fuel in the world.

\section{Transportation History Through The Newspapers}

A short time ago the Society came into possession of what is probably a unique collection. It is a potpourri from the history of transportation, fourteen bound volumes, and nearly twice as much loose material in boxes and folders - newspaper clippings, some of them dating back to the beginning of the last century, on turnpikes, canals, stages, taverns, railroads, steamboats, ferries, ships and shipbuilding, coal, express-riders, and every subject which could conceivably have had anything to do with transportation, including the ubiquitous lottery. The books are liberally illustrated with engravings, sketches and prints of the commercial cities of the world, scenes along the route of canals and railways, coaching parties and the like. This collection was the work of the late Mr. Benjamin Thomas Hill, of Worcester, in his spare time. It was acquired through the interest of Mr. Hill's heirs, and the coöperation of many of his former associates in the city of Worcester.

The books are arranged chronologically, but there is an elaborate index according to subject. Turning over the leaves of one of the volumes, the reader will find, perhaps, a pencil sketch of Cincinnati in 1829 , with a topheavy old side-wheel steamer in the foreground, followed by a hopeful announcement that work is to be commenced immediately on the Baltimore and Susquehanna Railroad. Rapid progress will undoubtedly be made, indeed twelve miles of the road should be completed within the year, "affording a practicable demonstration of the value and advantages of railroads." The extract continues in a bitter tone about a proposed improvement of the river Codorus by the citizens of York, suggesting that "their liberal, enlightened, and patriotic neighbors of the Aurora have a town meeting called in Philadelphia, to petition the legislature of Pennsylvania for the erection of a wall at least fifty cubits high, at the Maryland line, and thus effectually put a stop to the daring attempt of the Baltimoreans, and the people of Southern Pennsyl- 